\title{
POTRET IDEOLOGI PEMIKIRAN M SAID ASHMAWI TENTANG AYAT AHKAM DENGAN METODE KONTEKSTUAL
}

\author{
Bustami Saladin \\ Fakultas Ushuluddin dan Studi Agama \\ Universitas Islam Negeri Mataram
}

\begin{abstract}
Abstrack
The term syarî ah and several other terms that have the same root words in the Qur'an. He concluded that syarî̀ah means tariq (road), sabil (path, method), and manhaj (method). Therefore, syarîah can be interpreted as a way or method of Allah or Islam. In this sense also includes the rules of law revealed in the Qur'an, then the rules contained in Hadith (verbal tradition), and then tafsir, opinion-opinions, and ijtihâd (personal opinion), fatwâ (religious opinion ) ulamâ, and judges' decisions. In short, it encompasses all that complements and explains these fundamental rules for establishing Islamic jurisprudence (fiqh) as formed in history. Thus, in the Qur'an, it does not mean law (qânûn) or legislation (tashrf), so that the issue of applying Islamic syarîah is nothing but a mere human invention
\end{abstract}

Key words: Ideleogi, Muhammad Sa id al-Asymawi, syarîah, Ayat Ahkam 


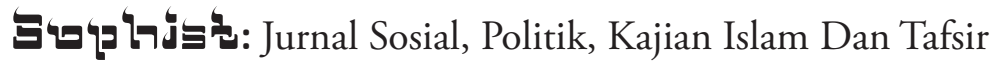

\section{A. Pendahuluan}

Dalam khazanah pemikiran liberal kontemporer, salah satu juru kampanye yang cukup berpengaruh adalah Muhammad Sa id al-Asymawi. Alumnus Fakultas Hukum Universitas Farouk II tahun 1955 ini pernah menjadi hakim di pengadilan negeri Kairo dan Alexandria, sebelum akhirnya menjabat sebagai kepala pengadilan tinggi. Di antara karya-karyanya: Ushūl al-Syariah (Prinsip-prinsip Syariah), al-Ribà wal' Fäidah $f i$ al-Isläm (Riba dan Bunga Bank dalam Islam), al-Isläm al-Siyāsi (Islam Politik), Jawhar al-Isläm (Esensi Islam), al-Khiläfah al-Islämiyah (Pemerintahan Islam), serta Haqiqat al-Hijāb wa Hujjiyat al-Sunnah (Hakikat Jilbab dan Validitas Sunnah sebagai Dalil). Namun, bukunya yang paling memicu kontroversi adalah $\mathrm{Al}$ Isläm al-Siyāsi dan Haqiqat al-Hijäb wa Hujjiyat al-Sunnah.

Sebagai seorang praktisi hukum kawakan, Asymawi sangat piawai bermain retorika serta logika. Dan ia memanfaatkan betul kepiawaian tersebut untuk menjual ide-ide liberalnya. Sehingga, sekilas, setiap argumen yang ia paparkan terdengar logis, dan dibungkus dengan kemasan retorika yang menarik.

Seperti pandangan penafsirannya tentang jilbab, misalnya, dengan mengutak-atik asbab nuzul ayat-ayat Al-Qur'an tentang jilbab, Asymawi terang-terangan mengatakan jilbab tidak wajib, dan sama sekali bukan bagian dari agama. Ia berusaha mengecoh publik dengan menyimpulkan bahwa jilbab hanya syariat yang bersifat temporal; berlaku di zaman Nabi SAW saja, karena alasan-alasan tertentu. ${ }^{1}$

Mantan dosen American University in Cairo (AUC) ini juga mempersoalkan status hadis $\bar{a} h \bar{a} d$ yang acap digunakan sebagai dalil diwajibkannya jilbab. Menurutnya, hadis yang diriwayatkan oleh seorang Sahabat Nabi saja (āhād), tidak bisa dijadikan landasan produk hukum yang diklaim sebagai syariat. Terlebih, yang mengandung konsekuensi pahala dan dosa.

1 Abdullah Hakam Shah https://ahmadbinhanbal.wordpress.com/2012/04/06/ pemikiran-liberal-muhammad-said-al-asymawi/ di kutip 10 Oktober 2018 
Tetapi bila menelaah pendapat ulama tafsir dan fikih dalam masalah ini, apa yang dilontarkan Asymawi terbukti hanya untuk memenuhi syahwat liberalnya semata. Argumen-argumennya tidak berdasar dan banyak mengandung celah kritik. Imam Abu Bakar alJashshāsh, al-Qurthubi, al-Khāzin, Ibnu 'Athiyyah, dan Ibnu Katsir - untuk menyebutkan sebagian saja - secara gamblang menegaskan wajibnya jilbab serta batasan-batasan aurat muslimah. Dan tak satu pun berpendapat bahwa itu hanya berlaku di zaman Nabi SAW. Begitu pula soal hadis $\bar{a} h \bar{a} d$. Sejak zaman Sahabat RA, hadis āhād disepakati bisa dijadikan landasan hukum. Baik dalam praktik ibadah maupun muamalat. Bahkan, dalam masalah-masalah akidah sekalipun.

Tak hanya soal jilbab, pemikiran liberal Asymawi juga menjamah rukun Islam yang keempat: zakat. Menurutnya, pemungutan zakat dari kaum muslim cuma hak Nabi SAW, dan tak seorang pun berhak melakukannya sepeninggal beliau. Apa yang dilakukan Abu Bakar r.a. dengan memerangi orang-orang yang tidak mau membayar zakat, merupakan suatu kelancangan atas hak prerogatif Nabi SAW

Sementara dalam "al-Isläm al-Siyāsi", di antara kampanye liberalisasi syariat ala Asymawi adalah tuntutannya agar sanksi bagi peminum Khamr dicabut. Karena, menurutnya, tak ada dalil yang mengatur sanksi bagi peminum dan penjual khamr. Baik dalam AlQur'an maupun sunah Nabi SAW. Lontaran-lontaran kontroversial semacam inilah yang kemudian mengantarkan Asymawi ke jajaran juru kampanye liberalisme garda depan.

Uniknya, lewat berbagai pemikiran liberalnya tersebut, Asymawi justru mengklaim sebagai seorang mujtahid. Dalam sebuah wawancara yang dimuat "Hiwār hawla Qadhāyā Islämiyah", ia menyatakan, "Selain kaum literalis yang jumud, saya yakin terdapat kaum rasional yang tercerahkan dalam umat ini. Mulai dari Muhammad Abduh, dan dilanjutkan oleh beberapa mujtahid

Kemunculan gerakan Islamis yang dahsyat di Mesir telah menarik perhatian para ilmuwan, sebagai usaha untuk mengontrolnya 
pada level politik dan kebijakan. Sedikit perhatian diberikan oleh orang-orang yang merespon tantangan ini pada level perdebatan ideologis. Salah seorang di antaranya adalah seorang hakim terkenal, Muhammad Sa'id al-'Ashmawi. Setidak-tidaknya, ia berpartisipasi dalam perdebatan yang sangat panjang tentang pada tingkat mana Islam dapat dikatakan benar-benar sebagai sebuah pedoman hidup yang lengkap.

Akar perdebata ini dapat dilacak pada abad ke-19 M, ketika Mesir mulai mengadopsi cara-cara Eropa dan menghasilkan secara eksplisit legislasi sekular, pertama di bawah pemerintahan sendiri dan kemudian di bawah pendudukan Inggris, ketika Muhammad Abduh dan lainnya memandang bagaimana cara-cara baru dapat dihubungkan dengan tradisi Islam. ${ }^{2}$

Perdebatan itu dapat dikatakan telah mendapatkan bentuk seperti saat ini setelah kemerdekaan Mesir 1922 dan digerakkan oleh reformasi sekularis di Turki. Penunjuknya adalah buku al-Islâm wa Ushûl alHukm, karya 'Alî abd al-Raziq, yang berusaha untuk menunjukkan berdasarkan sumber-sumber otoritas Islam bahwa kekuasaan politik bukan merupakan bagian dari misi kenabian Muhammad dan bahwa agama dan pemerintahan merupakan dua hal yang terpisah di dalam Islâm. ${ }^{3}$

Pada posisi yang berlawanan, Ikhwân al-Muslimîn, ${ }^{4}$ yang didirikan pada 1928, menyebut sebuah tatanan Islam, di mana Islam

2 Untuk masalah ini lihat Daniel Crecelius in "The Course of Secularization in Modern Egypt,» dalam Islam and Development, ed. J. Esposito (Syracuse, N.Y.: Syracuse University Press, 1980), hlm. 49-70; dan Hamid Enayat, Modern Islamic Political Thought (London and Basingstoke: Macmillan, 1982). Untuk Muhammad Abduh dan pemikir lainnya, lihat Albert Hourani, Arabic Thought in the Liberal Age (London: Oxford University Press, 1962).

3 Tentang 'Ali Abdal-Raziq dan kritiknya, lihat Hourani, Arabic Thought, hlm. 18392 dan Leonard Binder, Islamic Liberalism (Chicago: University of Chicago Press, 1988)

4 Saat ini di samping Ikhwân lama yang disebut dengan fundamentalis, terdapat juga kelompok Islam baru yang disebut dengan neofundamentalis. Tetapi tidak ada perbedaan mendasar di antara keduanya. Lihat Nazîh N.M. Ayubi, "The Political Revival of Islam: The Case of Egypt", dalam An Anthology of Contemporary Middle Eastern History, ed. Syafiq Mughni (Kanada: McGill University, t.th.), hlm. 571. 
harus menjadi ideologi pemerintah, hukum harus sesuai dengan syarîah Islam, sedangkan modernisasi dan nasionalisasi harus berada di bawah kerangkan Islâm. Kelompok ini terus berjuang untuk menegakkan sebuah negara Islâm. Menurutnya, Islâm adalah agama dan pemerintahan (dîn wa dawlah). ${ }^{5}$

Dalam suasana perdebatan ideologis tentang penerapan syarîah Islam inilah, dalam tulisan ini akan disajikan tentang pemikiran Muhammad Sa'id al-Ashmawi (selanjutnya disebut al-'Ashmawi) tentang syarîah dan penerapannya di Mesir.

Sekilas Tentang Al-'Ashmawi

Al-'Ashmawi lahir di Mesir pada 1931. Ia adalah lulusan Fakultas Hukum di Cairo University pada 1954. kemudian, ia menjadi pembantu jaksa wilayah dan selanjutnya menjabat sebagai jaksa wilayah di Alexandria. Pada 1961, ia diangkat sebagai hakim dan berturutturut menjadi hakim ketua pada Pengadilan Tinggi, Pengadilan Tinggi Banding, Pengadilan Kriminal Tinggi, dan Pengadilan Tinggi Keamanan Negara, yang telah menjatuhkan hukuman kepada orang-orang radikal Islâm yang melakukan kampanye menentang otoriterianisme negara Mesir. ${ }^{6}$

Ia juga mengembangkan keahliannya di bidang teologi Islâm (ushîl al-dîn) dan syarîah serta di bidang hukum komparatif. Tidak puas dengan itu, ia melanjutnya studinya di Harvard Law School dan di berbagai tenpat di USA pada 1978. Ia mengembangkan karir sebagai dosen di American University di Kairo, di samping juga berbagai universitas dan institute di Eropa dan Amerika Serikat. Selama masa ini, ia dikenal sebagai pengeritik yang luar biasa terhadap kecenderungan Islâmisis, dan telah menulis sejumlah besar artikel dan buku. Karenanya, pada 1979 ia mendapat ancaman pembunuhan dari

5 Sana Abed-Kotob, “The Accomodation Speak: Goals and Strategies of the Muslim Brotherhood of Egypt", dalam An Anthology of Contemporary Middle Eastern History, ed. Syafiq Mughni (Kanada: McGill University, t.th.), hlm. 546-547.

6 Muhammad Sa'id al-'Ashmawi, Islâm and the Political Order (Washington: Council for Research in Values and Philosophy, 1994), hlm. 17. Buku ini merupakan terjemahan dari bahasa Arab, al-Islâm al-Siyâsi (Kairo: Sina li-l-Nashr, 1986) 
kalangan Islâmis. Alasannya, karena ia menafsirkan al-Qur'ân sesuai dengan konteks historisnya, yang dipahami oleh kaum Islâmis sebagai merusak validitas agamanya. Pada Januari 1980, penguasa Mesir memintanya untuk mendapatkan kawalan polisi. ${ }^{7}$ Sejak pengunduran diri dari hakim pada 1993, ia meneruskan usaha ini, walaupun, sekali lagi, terdapat ancaman kematian dari kalangan ekstremis sehingga ia harus mendapatkan perlindungan polisi selama $24 \mathrm{jam}$.

Dia juga sempat berpolemik dengan al-Azhar karena mengkritik legalitas yang diberikan kepada institusi ini untuk menyensor musik, film dan video. Kritikannya ini telah menimbulkan kemarahan ulama al-Azhar sehingga sempat melarang peredaran buku-bukunya untuk sementara di Cairo Book Fair pada 1992. Pelarangan itu baru ditarik kembali setelah intervensi presiden Mesir Husni Mubarak. Menghadapi situasi yang mengencam saat ini, ia berkata, "Saya yakin, saya memiliki sebuah misi. Saya sama sekali tidak khawatir dengan kaum ekstremis Islâm. saya yakin, pembunuhan terhadap saya menjadi bagian dari misi saya". ${ }^{8}$

Argumen dasar al-'Ashmawi adalah bahwa Islâmisme, terutama dalam bentuknya yang lebih ekstrem, adalah berlawanan dengan Islâm. Nama yang biasa ia gunakan untuk Islâmisme adalah "Islâm politik", sebuah label yang diberikan untuk merelativisasikan klaim kaum Islâmisis dengan berargumentasi bahwa mereka hanya menampilkan salah satu bentuk Islâm dan bukan Islâm yang semacam itu. Dalam pandangan mereka, yang paling ekstrem, perdebatan adalah antara Islâm dan kufr. Sedangkan dalam pandangan al-'Ashmawi, perdebatan

7 A. Dankowitz, "Arab Intellectuals: Under Threat by Islâmists", Inquiry and Analysis, No. 254 (November 2005), hlm. 1.

8 Ibid., hlm. 2.

9 Nama sama dengan judul asli bukunya yang tulis, yaitu al-Islâm al-Siyâsi, sebagaimana pada foot note 1 . Ketika karyanya ini diterbitkan di Mesir pada 1986, kalangan konservatif marah, termasuk rektor Universitas Islam yang dikelola pemerintah, Syaykh alAzhar. Sebaliknya, publikasi karya tersebut membuat senang kelompok liberal, bahkan juga kelompok-kelompok oposisi yang jarang bersimpati pada pejabat-pejabat tinggi pemerintah. Baca David Sagiv, "Judge 'Ashmawi and Militant Islam in Egypt", Middle Eastern Studies, Vol. 28 No. 3 (July 1992). 
itu terjadi antara "Islâm politik" (political Islâm) dan "Islâm yang tercerahkan" (enlightened Islâm). ${ }^{10}$

Ia beralasan bahwa penyebutan "penerapan syarîah" (tatbîq alsyarîah) atau kodifikasi syarîah (taqnîn al-syarîah), semboyan dari gerakan Islâmis, sesungguhnya tidak lebih dari sekedar slogan kosong, yang dimaksudkan untuk mendapatkan dukungan rakyat menuju sebuah usaha politik tetapi tidak jelas sama sekali dan secara substansial mungkin tidak signifikan. Namun demikian/lebih dari itu, sebuah pengujian tentang sifat dasar syarîah menunjukkan bahwa, pertama, mereka betul-betul masih bingung dengan istilah syarîah dan fiqh, dan kedua, bahwa hukum Mesir konsisten dengan syarîah. Dua point ini merupakan inti persoalan yang menempatkana al-'Ashmawi dalam parameter perdebatan akhir-akhir ini.

\section{B. Pembahasan}

\section{Kontekstualitas Ayat Ahkam Dalam Bingkai Syari'ah Menurut Muhammad Said Asymawi}

Dalam bukunya Ushul Asy-Syari'ah menulis tentang kegelisahannya dari (mungkin) banyaknya negara-negara Islam yang mencantumkan kata-kata syariah islamiyah sebagai sumber utama legislasi hukum negaranya, seperti Mesir, Syiria, dan Libia. Pasalnya, masih banyak dewan legeslatif yang belum memahami arti bahasa kata syariah sendiri, sehingga hasil-hasil putusan hukumnya terkesan jauh dari yang diharapkan dan terlalu ekskusif. Lebih parahnya lagi, menurut Muhammad Said, para dewan legeslatif telah melakukan kekeliruan yang besar karena telah mencampur aduk antara syariat dengan fiqih. Pasalnya Muhammad Said memandang bahwa antara syariah dengan fiqih itu memiliki perbedaan yang krusial. Selain itu para dewan legeslatif (hukum) menyangka bahwa syariat adalah sistem undang-undang, padahal menurut Muhammad Said, syariah itu lebih

10 William E. Shepard, "Muhammad Sa'id al-'Ashmawi and the Application of the Sharia in Egypt", International Journal of Middle East Studies, Vol. 28, No. 1 (Feb., 1996), hlm. 43 . 
universal dan lebih menyeluruh, karena syariat merupakan inti yang membentuk undang-undang itu sendiri. Sedangkan fikih adalah hasil pemikiran-pemikiran mujtahid yang sangat relative. Muhammad Said khawatir akan terjadi adanya skralisasi fiqih yang dianggap sejajar dengan syariah.

Muhammad Said memandang bahwa syariat bukanlah kaidahkaidah, aturan-aturan, dan hukuman-hukuman, melainkan spirit yang menembus inti segala sesuatu. Sebuah spirit yang berkelanjutan dalam menciptakan aturan-aturan baru, melakukan pembaruan-pembaruan dan interpretasi modern. Syariah menurutnya adalah sebuah gerak langkah dinamis yang selalu membawa manusia pada tujuan-tujuan yang benar dan orientsi-orientasi yang mulia supaya mereka tidak terjebak ke dalam teks, terkoyak dalam lafal, dan tenggelam dalam ungkapan. ${ }^{11}$

Untuk menguatkan argumennya, Muhammad Said menelusuri akar bahasa kata syariah terlebih dahulu dari berbagai kitab suci, seperti Taurat, Talmud, Injil, dan Al-Qur'an. Dalam kitab-kitab tersebut ditemukan akar bahasa syariat, meskipun dengan ungkapan yang berbeda-beda. Menurutnya, penggunaan kata "syariat" telah dimulai dalam kitab-kitab Musa a.s. dengan arti "jalan yang telah ditentukan dan kokoh untuk ritual-ritual dan perantara-perantara ritual yang lurus" sampai pada sejarah mesir kuno yang menyatakan bahwa jalan yang landasan yang kokoh dan lurus itu adalah yang dikerjakan oleh dewa Maat. Yaitu dewa kepercayaan mesir kuno yang mempunyai sifat adil, benar, dan jujur.

Al-Masih menggunakan kata Numus dengan makna yang dimaksudkan dalam kitab Nabi Musa a.s. adapun dalam Al-Qur'an, kata "syariat" muncul dengan arti "jalan masuk, jalan, dan metode". Penggunaan ini menyerupai penggunaan kata "syariat" dalam kitab Nabi Musa a.s., meskipun mungkin dalam kitab-kitab Nabi Musa a.s.

11 Abdullah Hakam Shah https://ahmadbinhanbal.wordpress.com/2012/04/06/ pemikiran-liberal-muhammad-said-al-asymawi/ di kutip 15 Oktober 2018 
itu mengandung makna "kejujuran dan kekokohan, dimana maksudnya adalah jalan yang tetap dan metode yang lurus". Pemahaman yang sama ini, menurut Muhammad Said, bukan merupakan sekedar isyarat kebetulan, melaikan telah menjadi sebuah petunjuk akan adanya serentetan pemahaman dan saling kait mengaitnya kata-kata melalui satu makna, yang berpindah dari satu peradaban ke peradaban yang lain dan dari agama ke agama yang lain, sedangkan dalam makna hakikinya merupakan satu asal yang memiliki inti yang tidak berubah dan berganti.

Namun, Muhammad Said menyayangkan, pada akhirnya pemahaman kata syariah dalam pemikiran Islam berubah menjadi “sistem Islam” yang meliputi Al-Qur'an, Hadits, Ijma', dan Qiyas. Yakni meliputi keseluruhan tradisi Islam, seperti kitab-kitab samawi, ucapan-ucapan dan perbuatan Nabi Muhammad saw. Serta kesepakatan-kesepekatan para ulama dan qiyas yaitu analogi seorang mujtahid untuk memutuskan suatu hukum atau kaidah.

Perubahan ini menurut Muhammad Said sangat berbahaya karena mencampur adukkan antara agama (adalah apa yang datang dari nabi Muhammad saw., baik berupa Al-Qur'an ataupun hadits) dengan pemikiran keagamaan (metode-metode histories untuk memahami dasar-dasar agama dan penerapannya). Dan yang akan terjadi adalah pensakralan pemikiran keagamaan (fiqih).

Maka dari itu, dalam bukuknya Muhammad Said mencoba mengemukakan pondasi-pondasi umum (al-ushul 'ammah) yang istimewa pada "syariat" yang tidak berhenti pada kaidah-kaidah umum yang sama, yang terdapat dalam berbagai syariat. Ujarnya, pembatasan pondasi-pondasi umum ini akan sangat membantu menyelesaikan problematika penerapan syariat, selama yang dimaksud adalah upaya pemahaman yang dilakukan akal atas keistimewaan syariat, bukan yang lain. Yakni, Al-Qur'an melalui tinjauan sejarah, dengan mencermati ayat-ayatnya satu persatu berdasarkan waktu turunya ayat, sebab-sebab, tujuan, dan hikmah-hikmahnya, sehingga 
dimungkinkan mendapatkan kejelasan tentang tujuan-tujuan Allah.

Dengan pemahaman seperti itu, Muhammad Said meringkas prinsip-prinsip (syariat) secara global menjadi enam; yang Pertama, penurunan syariat berhubungan dengan berdirinya masyarakat-agama, dan penerapannya bergantung pada keberadaan masyarakat ini. Kedua, syariat turun karena ada sebab-sebab yang menghendakinya, dan sebab-sebab turunya syariat itu tidak memiliki kesesuaian dengannya. Ketiga, syariat bertujuan demi kemaslahatan umum masyarakat. Untuk merealisasikan kemaslahatan ini, sebagian syariat menghapus sebagian yang lain. Kebenaran dan kemaslahatn syariat bergantung pada kemajuan realitas yang terus berubah dan peristiwa yang senantiasa baru. Keempat, sebagian hukum-hukum syariat dikhususkan kepada Nabi Muhammad saw., dan sebagian yang lain dikhususkan pada suatu peristiwa. Kelima, hubungan syariat dengan masa lalu tidak terputus, akar-akarnya juga tidak terputus dari masyarakat tempat diturunkan syariat, tetapi syariat mengambil sesuatu dari pranata-pranata dan budaya-budaya masyarakat untuk dijadikan sebagai hukum. Keenam, agama telah sempurna, sedangkan kesempurnaan syariat adalah upayanya yang selalu berkesinambungan untuk menyesuaikan diri dengan kondisi masyarakat dan mengarahkan manusia pada esensi kemanusiaan dan semangat kehidupan.

Sebagaitawaranpemikirannya,MuhammadSaidmengungkapkan beberapa dasar-dasar penerapan syariat dimulai dengan masalah hubungan internasional, yakni dengan memahami mana kawan dan lawan. Sehingga dalam situasi seperti ini muncul pemikiran bahwa Negara Islam itu ada ketika di sana ditemukan agama Islam, dan pemikiran bahwa Negara Islam adalah wilayah perdamaian (dar assalam) dan selain itu adalah wilayah peperangan (dar al-harb).

Kemudian Muhammad Said menawarkan agar dibahas tentang tema-tema hukum internal, seperti hukum perdata, pidana, perkara-perkara sipil, dan harta warisan. Untuk menerapkannya Muhammad Said juga menguraikan dasar-dasar pemerintahan dalam 
syariat. Muhammad Said juga mengakui bahwa syariat tidak pernah menyebutkan suatu sistem pemerintahan. Hanya saja ketika syariat -dalam makna yang shahih- diartikan sebagai metode, maka syariat itu, harus berjalan seiring dengan setiap kemajuan dan perkembangan. Dengan keagungan hukum-hukum Islam menyuguhkan prinsip dan nilai-nilai yang mulia, sehingga dengannya masyarakat abad pertengahan mengalami kejayaan.

Menurutnya, dalam syariat terdapat kebebasan berakidah, prinsip tentang kebebasan manusia, penghormatan terhadap perempuan serta prinsip-prinsip yang mulia lainnya. Oleh karena itu, lanjutnya, upaya penerapan syariat berarti mengambil metodenya yang bijaksana demi kemajuan manusia menuju cakrawala yang lebih mulia, dan kemajuan kemanusiaan menuju martabat yang lebih terhormat. Tandasnya lagi, sistem pemerintahan Islam yang benar adalah sistem yang bersumber dari realitas masyarakat dan kehendak generasinya dan berjalan atas partispasi setiap individu dalam setiap tanggung jawab pemerintah, legislasi, dan pengawasan. Ia akan senantiasa mengiringi perkembangan dan kemajuan dunia, kemudian mengambil prinsip-prinsip yang paling mulia mengenai kebebasan, keadilan, dan persamaan, mengambil kaidah-kaidah yang mulia dalam hal kebijakan dan aturan-aturan, serta dasar-dasar mengenai sistem pendidikan dan pengajaran. Ia juga mengambil bentuk sistem pemerintahan yang universal dan sistem yang paling dekat pada keadaan-keadaan lingkungannya, tabiat sosial, dan nilai-nilainya yang hakiki.

Lanjutnya lagi, sistem pemerintahan Islam adalah sistem yang menghormati manusia dan tidak berkutat pada teks. Ia sangat concern terhadap kemanusiaan dan tidak terjebak pada pendapat-pendapat. Tetapi sistem pemerintahan Islam adalah sistem yang berjalan sesuai dengan kemuliaan di atas jalan kebenaran. Di dalamnya setiap individu adalah kebenaran, keadilan, dan konsistensi. Itulah jalan, metode, dan cara. Itulah hakikat eksistensi dan kehidupan serta alam semesta, tuturnya. 
Buku ini menarik untuk dibaca, karena buku ini menyajikan pandangan-pandangan yang berbeda dari kebanyakan ulama tempo dulu. Buku ini ingin mengantarkan para pemegang kebijaksanaan (dewan legeslatif) agar lebih bijaksana dan arif dalam mengambil atau merumuskan suatu undang-undang Negara. Walaupun demikian, buku ini masih memiliki kekurangan dan perlu adanya kajian lebih mendalam. Ungkapan Muhammad Said yang menyatakan bahwa semua ayat-ayat Al-Qur'an memiliki sebab-sebab turunya ayat agaknya harus dikoreksi kembali, karena ada beberapa ayat yang tidak didahului oleh peristiwa-peristiwa yang menyebabkan turunnya ayat Al-Qur'an.

Selain itu, Muhammad Said sangat kritis terhadap pemangku kebijakan yang mencampur adukkan antara syariat dengan fiqih. Namun, pada akhir pembahasannya, Muhammad Said juga tidak konsisten dengan krtikikannya. Terbukti ketika Muhammad Said menguraikan dasar-dasar syariat dan dasar-dasar pemerintahan Islam yang sarat dengan kajian-kajian fiqih. Kalau demikian adanya, maka tidaklah salah jika dewan legeslatif menjadikan fiqih sebagai landasan negaranya selama itu sesuai dengan kemaslahatan umum dan untuk kemajuan umat Islam agar lebih mulia. Dan tidak salah kalau suatu waktu hokum yang sudah ditetapkan akan berubah sesuai dengan kebutuhan masyarakat yang mengelilinginya.

Al-Ashmawi menguji istilah syarîah dan beberapa istilah lainnya yang memiliki akar kata yang sama dalam al-Qur'an. ${ }^{12}$ Ia menyimpulkan bahwa syarîahbermakna tariq (jalan), sabil (jalan, cara), dan manhaj (metode). ${ }^{13}$ Karenanya, syarîah dapat dimaknai sebagai jalan atau metode Allâh atau Islâm. Dalam pengertian ini tercakup

12 Al-Qur'ân menyebut istilah syarîa h hanya satu kali, yaitu dalam surat al-Jâtsiyah (45): 18. Istilah-istilah lain yang seakar dengannya, masing-masing, terdapat dalam surat al-Syûrâ (42): 13, al-Mâ'idah (5): 48, dan al-Syûrâ (42): 21.

13 Makna al-Qur'ân inilah yang dimunculkan dalam kamus-kamus bahasa Arab. Misalnya dalam Lisân al-'Arab, kata syarî̀ah dimaknai sebagai menuju ke air, memberi minum atau jalan atau lembah menurun menuju air. Periksa Muhammad Fuad Abd alBâqî, Lisân al-'Arab (Beirut: Dâr al-Fikr, t.th.), pada kata syara’a. 
pula aturan-aturan hukum yang diwahyukan dalam al-Qur'ân, lalu aturan-aturan yang terdapat dalam Hadîts (verbal tradition), dan selanjutnya tafsîr, pendapat-pendapat, dan ijtihâd (personal opinion), fatwâ (religious opinion) ulamầ, dan keputusan-keputusan hakim. ${ }^{14}$ Singkatnya, ia mencakup semua yang melengkapi dan menjelaskan aturan-aturan fundamental ini untuk menetapkan yurisprudensi Islâm (fiqh) sebagaimana terbentuk dalam sejarah. Dengan demikian, dalam al-Qur'an, ia tidak berarti hukum (qânûn) atau legislasi (tashrf), sehingga isu penerapan syarîa Islam tidak lain hanya rekaan manusia semata.

Selanjutnya, al-Ashmawi menjelaskan bahwa pada awalnya istilah syarîah mencakup semua aturan yang berkenaan dengan ibadah dan masyarakat yang ada di dalam al-Qur'an, al-Sunnah. Tetapi dalam perkembangannya selanjutnya, istilah itu melebar sehingga mencakup ijtihâd para ulamâ. Padahal yang terakhir ini lebih tepat disebut sebagai fiqh. ${ }^{15}$ Dengan demikian, mereka yang menuntut penerapan syarîah, katanya, sesungguhnya bukan menuntut pengaplikasian Islam secara utuh tapi menuntut penerapan ijtihâd 'ulamâ' (fiqh) seperti yang tercantum dalam kitab fiqh klasik. ${ }^{16}$

14 Muhammad Sa’id al-'Ashmawi, "Syari'ah: Kodifikasi Hukum Islam”, dalam Wacana Islam Liberal: Pemikiran Islam Kontemporer tentang Isu-isu Global, ed. Charles Kurzman, (Jakarta: Paramadina bekerjasama dengan Yayasan Adikarya IKAPI dan The Ford Foundation, 2001), hlm. 41.

15 Shepard, "Muhammad Sa'id al-'Ashmawi”, hlm. 43. Tentang fiqh, para 'ulamâ' mendefinisikannya sebagai hasil ijtihâd para 'ulamâ', oleh sebab itu ia terkadang berubah sesuai dengan dalil dan juga kondisi nyata yang berlaku ditengah masyarakat. Namun demikian, ini bukan berarti bahwa figh produk pikiran manusia semata atau hasil rekayasa para fuqahâ'. Dalam pendefinsian fiqh, para 'ulama lazimnya menggunakan dua perkataan,

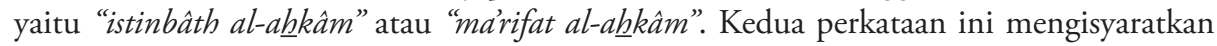
bahwa tugas para fuqahâ' hanyalah menderivasi atau mengetahui hukum saja. Artinya para fuqahâ berusaha "menampakkan" hukum yang pada prinsipnya sudah ada dalam teksteks aslinya akan tetapi tidak dapat ditangkap dengan mudah oleh kebanyakan orang. Makanya ia disebut fiqh, yang oleh Abû Muzaffar al-Sam'ani dikatakan "istinbâth hukm al-musykil min al-wadih" (mengeluarkan hukum yang rumit dari sesuatu yang jelas). Lihat Abu Ishaq Ibrâhim al-Syirazi, Syarh al-Luma,' Jilid I (Bayrut: Dâr al-Gharb al-Islâmi, 1989), hlm. 158-9; dan Abû Muzaffar al-Sam'ani Qawâti' al-Adillah fì al-Ushîl,, (Bayrut: Muassasah al-Risâlah, 1996), hlm. 33.

16 Perbedaan antara syarîah dengan fiqhbukan barang baru dalam wacana pemikiran 
Kekacauan antara syarîah dan fiqh berarti kekacauan antara kehendak Allâh dengan pendapat dan tindakan manusia. Ini adalah masalah yang ia tegaskan berkali-kali. Karenanya, kita seyogyanya kembali kepada penggunaan yang tepat, di mana syarîah hanya mencakup nilai-nilai, prinsip-prinsip, dan hukum-hukum yang ada di dalam al-Qur'ân dan al-Sunnah, karena hanya keduanya yang dipelihara dari kesalahan oleh Allâh. Semua deduksi atau asumsi dari keduanya dan semua komentar yang berdasarkan atasnya, merupakan usaha manusia yang bisa salah dan berada di bawah kerangka fiqh.

Namun demikian, sebagai jalan atau metode Allâh, syarîah mencakup sesuatu yang lebih fleksibel ketimbang fiqh. Al-'Ashmawi menyebutnya sebagai sebuah jiwa, sebuah metode, dan sebuah gerakan, yang, muncul untuk, memasukkan dan memperbarui hukum-hukum tetapi tidak menahan di dalamnya. ${ }^{17}$ Syarîah dibedakan tidak oleh pendapat tertentu, tetapi oleh "metode dinamik yang dapat membuat seseorang dan masyarakat berbudi luhur dan shalih. Ia adalah semangat yang menjadikan dan menghasilkan sebuah masyarakat yang adil di depan hukum dan prinsip-prinsip hukumnya diterapkan. Kemudian, "menerapkan syarîah" seharusnya dimaknai sebagai mengadopsi metodenya untuk kemajuan terbesar individu dan kemanusiaan. ${ }^{18}$

hukum Islam. Para 'ulamâ sejak dulu sudah melakukan pembedaan ini. Perkataan syarî'ah mencakup seluruh aspek Islam, yakni hukm, 'aqîdah dan akhlâq. Ia menjadi identik dengan Islam. Kata Ibn Athir, sebagaimana dikutip oleh Yûsûf Hamîd al-'Alim, syarî̀ah adalah ketentuan agama yang diwajibkan Allâh atas hamba-Nya. Berdasarkan definisi ini berarti syarîah sama dengan Islam. Fiqh juga demikian. Pada awalnya, fiqh, sebagaimana


seseorang tentang hak dan kewajibannya). Dengan definisi ini, fiqh meliputi semua aspek kehidupan, yakni 'aqîdah, hukm, dan akhlâq. Ini berarti bahwa syarîah sama dengan fiqh. Tetapi kemudian, secara gradual istilah fiqh mengalami penyempitan dan akhirnya diaplikasikan secara khusus pada masalah-masalah hukum dan literaturnya. Untuk pembahasan berbagai masalah ini baca Yûsûf Hâmid al-'Alim, al-Maqâsid al-Ammah li Syarîah al-Islamiyyah (Virginia: al-Ma'had al'Alami li al-Fikr al-Islâmî, 1991), hlm. 20; Ahmad al-Bayâdî, Isyârat al-Maram min 'Ibârat al-Imâm (Kairo: Dâr al-Jayl, 1949), hlm. 28-29; dan Mahmûd Syalthûth, al-Islâm 'Aqîdah wa al-Syarîa t.tp.: Dâr al-Qalam, 1966), hlm. 12.

17 Sagiv, "Judge 'Ashmawi and Militant Islam in Egypt", hlm. 532.

18 Shepard, "Muhammad Sa'id al-'Ashmawi”, hlm. 44. 
Namun demikian, orang-orang yang menggunakan slogan tersebut sesungguhnya menyebut aplikasi fiqh, yakni serangkaian aturan dan hukum yang difikirkan dan ditetapkan oleh manusia, bukan oleh Allâh, untuk mempertemukan kondisi historis masa lalu yang tidak lagi berlaku. Fiqh tidak berada di dalam otoritas Allâh dan tidak memiliki fleksibilitas untuk memberikan solusi Islâmi tentang berbagai kebutuhan kontemporer.

\section{Kesimpulan}

Al-Ashmawi memandang bahwa syariat bukanlah kaidahkaidah, aturan-aturan, dan hukuman-hukuman, melainkan spirit yang menembus inti segala sesuatu. Sebuah spirit yang berkelanjutan dalam menciptakan aturan-aturan baru, melakukan pembaruan-pembaruan dan interpretasi modern. Syariah menurutnya adalah sebuah gerak langkah dinamis yang selalu membawa manusia pada tujuan-tujuan yang benar dan orientsi-orientasi yang mulia supaya mereka tidak terjebak ke dalam teks, terkoyak dalam lafal, dan tenggelam dalam ungkapan

Al-Ashmawi menguji istilah syarîah dan beberapa istilah lainnya yang memiliki akar kata yang sama dalam al-Qur'an. Ia menyimpulkan bahwa syarîah bermakna tariq (jalan), sabil (jalan, cara), dan manhaj (metode). Karenanya, syarîah dapat dimaknai sebagai jalan atau metode Allâh atau Islâm. Dalam pengertian ini tercakup pula aturan-aturan hukum yang diwahyukan dalam al-Qur'ân, lalu aturan-aturan yang

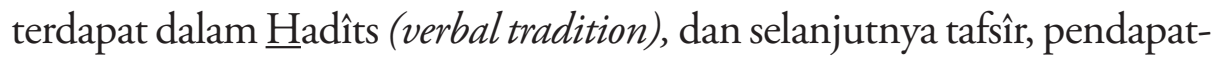
pendapat, dan ijtihâd (personal opinion), fatwâa (religious opinion) ulamâ, dan keputusan-keputusan hakim. Singkatnya, ia mencakup semua yang melengkapi dan menjelaskan aturan-aturan fundamental ini untuk menetapkan yurisprudensi Islâm (fiqh) sebagaimana terbentuk dalam sejarah. Dengan demikian, dalam al-Qur'an, ia tidak berarti hukum (qânûn) atau legislasi (tashrf), sehingga isu penerapan syarîab Islam tidak lain hanya rekaan manusia semata 


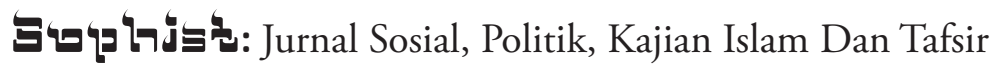

Adapun dalam Al-Qur'an menurut Al-'Ashmawi kata "syariat" muncul dengan arti "jalan masuk, jalan, dan metode". Penggunaan ini menyerupai penggunaan kata "syariat" dalam kitab Nabi Musa a.s., meskipun mungkin dalam kitab-kitab Nabi Musa a.s. itu mengandung makna "kejujuran dan kekokohan, dimana maksudnya adalah jalan yang tetap dan metode yang lurus". Pemahaman yang sama ini, menurut Muhammad Said, bukan merupakan sekedar isyarat kebetulan, melaikan telah menjadi sebuah petunjuk akan adanya serentetan pemahaman dan saling kait mengaitnya kata-kata melalui satu makna, yang berpindah dari satu peradaban ke peradaban yang lain dan dari agama ke agama yang lain, sedangkan dalam makna hakikinya merupakan satu asal yang memiliki inti yang tidak berubah dan berganti. 


\section{Daftar Pustaka}

Muhammad Sa'id al-'Ashmawi, Islâm and the Political Order (Washington: Council for Research in Values and Philosophy, 1994)

A. Dankowitz, "Arab Intellectuals: Under Threat by Islâmists", Inquiry and Analysis, No. 254 (November 2005)

David Sagiv, "Judge 'Ashmawi and Militant Islam in Egypt", Middle Eastern Studies, Vol. 28 No. 3 (July 1992).

William E. Shepard, "Muhammad Sa'id al-Ashmawi and the Application of the Sharia in Egypt", International Journal of Middle East Studies, Vol. 28, No. 1 (Feb., 1996)

Muhammad Fuad Abd al-Bâqî, Lisân al-'Arab (Beirut: Dâr al-Fikr, t.th.)

Muhammad Sa'id al-'Ashmawi, "Syari'ah: Kodifikasi Hukum Islam”, dalam Wacana Islam Liberal: Pemikiran Islam Kontemporer tentang Isu-isu Global, ed. Charles Kurzman, (Jakarta: Paramadina bekerjasama dengan Yayasan Adikarya IKAPI dan The Ford Foundation, 2001)

Abu Ishaq Ibrâhim al-Syirazi, Syarh al-Luma', Jilid I (Bayrut: Dâr al-Gharb al-Islâmi, 1989)

Abû Muzaffar al-Sam'ani, Qawâti' al-Adillah fî al-Ushîl, (Bayrut: Muassasah al-Risâlah, 1996)

Yûsûf Hâmid al-'Alim, al-Maqâsid al-'Ammah li Syarî'ah al-Islâmiyyah (Virginia: al-Ma'had al'Alami li al-Fikr al-Islâmî, 1991)

Ahmad al-Bayâdî, Isyârat al-Maram min 'Ibârat al-Imâm (Kairo: Dâr al-Jayl, 1949)

Mahmûd Syalthûth, al-Islâm 'Aqîdah wa al-Syarî'ah t.tp.: Dâr alQalam, 1966. 


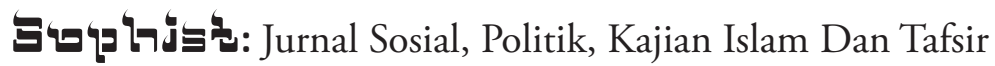

Al-'Ashmawi, al-Ribâ wa al-Fa'idah fì al-Islâm (Kairo: Dâr Sinâ, 1988)

Nazîh N.M. Ayubi, "The Political Revival of Islam: The Case of Egypt", dalam An Anthology of Contemporary Middle Eastern History, ed. Syafiq Mughni (Kanada: McGill University, t.th.)

Afaf al-Sayyid Marsod, Egypt in the Reign of Muhammad Ali (Cambridge: Cambridge University Press, 1984.

Mun'im A. Sirry, Sejarah Figh Islam; Sebuah Pengantar (Surabaya: Risalah Gusti, 1996.

Romli SA., Muqaranah Mazahib fil Ushul, (Jakarta: Gaya Media Pratama, 1999)

Daniel Crecelius in "The Course of Secularization in Modern Egypt," dalam Islam and Development, ed. J. Esposito (Syracuse, N.Y.: Syracuse University Press, 1980)

Hamid Enayat, Modern Islamic Political Thought (London and Basingstoke: Macmillan, 1982)

Albert Hourani, Arabic Thought in the Liberal Age (London: Oxford University Press, 1962). 